\title{
MARKET CONCENTRATION AND FOREIGN DIRECT INVESTMENT IN THE FINANCIAL LEASING SECTOR OF THE REPUBLIC OF SERBIA
}

\author{
Marija Radulović* \\ Faculty of Economics in Kragujevac \\ University of Kragujevac, Republic of Serbia
}

\begin{abstract}
The financial leasing market in previous years is characterised by a growth that is also expected in the coming period. Besides, developing countries are striving to attract as much foreign direct investment (FDI) as possible to accelerate economic growth and achieve macroeconomic stability. The aim of this paper is to determine whether there is a relationship between FDI and the level of market concentration in the financial leasing sector of the Republic of Serbia and to determine whether this relationship is long-term or short-term. Quarterly data from the first quarter of 2006 to the first quarter of 2019 were used. Autoregressive Distributed Lag approach (ARDL) and bounds test were used for data analysis. The results showed that there is a negative relationship between FDI and the level of market concentration in the financial leasing sector of the Republic of Serbia in the long run, while there is no statistically significant relationship between FDI and the level of market concentration in the short run.
\end{abstract}

Keywords: foreign direct investment, market concentration, financial leasing, Herfindahl-Hirschman Index, Republic of Serbia

JEL classification: L11, F23

\section{TRŽIŠNA KONCENTRACIJA I STRANE DIREKTNE INVESTICIJE U SEKTORU FINANSIJSKOG LIZINGA REPUBLIKE SRBIJE}

Sažetak: Tržište finansijskog lizinga u prethodnim godinama karakteriše rast koji se očekuje i u narednom periodu. Pored toga, zemlje u razvoju se trude da privuku što više stranih direktnih investicija (SDI) kako bi ubrzale ekonomski rast i postigle

\footnotetext{
*marijaradulovicvb@gmail.com
} 
makroekonomsku stabilnost. Cilj ovog rada je da se utvrdi da li postoji povezanost između SDI i nivoa tržišne koncentracije u sektoru finansijskog lizinga Republike Srbije, kao i da se utvrdi da li je ta povezanost dugoročna ili kratkoročna. Korišćeni su kvartalni podaci za period od prvog kvartala 2006. godine do prvog kvartala 2019. godine. Pri analizi podataka je primenjen autoregresivni model distribuiranih docnji $(A R D L)$ i test graničnih vrednosti (bounds test). Rezultati su pokazali postojanje negativne povezanosti između SDI i nivoa tržišne koncentracije u sektoru finansijskog lizinga Republike Srbije na duži rok, dok u kratkom roku nije utvrđena statistički značajna povezanost između istraživanih varijabli.

Ključne reči: strane direktne investicije, tržišna koncentracija, finansijski lizing, Herfindahl-Hirschman Index, Republika Srbija

\section{INTRODUCTION}

Financial leasing is a type of leasing that essentially transfers the risks and benefits of owning an asset, from the lessor to the lessee. However, the lessee is not the formal owner of the asset and the risks related to potential losses due to unused capacity, technological obsolescence, etc. The benefits represent expected earnings during the economic life of the asset (Čavić, 2009). As a specific form of financing, leasing is of great importance for the development of the entire economy, especially for the segment of small and medium enterprises, newly established enterprises and for agricultural holdings (Drljača, 2015). Precisely because of the importance of financial leasing, the sector must be well developed and have a large number of competitors on the market, both national and foreign. Foreign companies influence the progress of the host country by changing the market structure. Blomstrom (1986) argues that FDI in small economies increases market concentration due to the size and degree of technological sophistication of foreign compared to national companies.

The global financial leasing market is expected to grow significantly by 2025 , in line with the growing demand for expensive machinery, equipment and other necessary assets in the fields of healthcare, construction, information technology and telecommunications (Grand View Research, 2019). Accordingly, the subject of this empirical study is the financial leasing market of the Republic of Serbia and its characteristics with special emphasis on foreign companies in this sector. The aim of this paper is to determine whether there is a relationship between FDI inflows and the level of market concentration in the financial leasing sector of the Republic of Serbia, as well as to determine whether this relationship is long-term or short-term. The author will strive to prove that FDI inflows affect the level of market concentration in the financial leasing sector of the Republic of Serbia. Pack and Sagi (2001) 
consider that FDI influences the change of the market structure of the host country by increasing or decreasing the market concentration and thus influencing the conditions of competition. Suppose foreign companies enter a highly concentrated industry, opening new branches in the form of greenfield investments. In that case, the initial impact of FDI will lead to an increase in the number of companies in the market, increased competition and reduced market concentration. The long-term effects of FDI on the level of market concentration in the host country will depend on the competitive strength and technological capabilities of national companies.

Descriptive statistics, unit root tests, bounds tests and the AutoRegressive Distributed Lag (ARDL) approach were used to analyse the collected data.

Besides the introductory and concluding remarks, the paper is structured as follows. The first section provides an overview of the existing empirical literature on the relationship between FDI and the level of market concentration. The second part presents the data and research methodology. The third part presents the results of research on the relationship between FDI and the level of market concentration in the financial leasing sector of the Republic of Serbia.

\section{LITERATURE REVIEW}

The relationship of FDI to the number and distribution of companies in a given sector is a problem that economists have been dealing with for decades, and should answer two questions: do multinational companies open their branches abroad in industries with different market structures than national companies and what impact multinational companies have on the market structures of these sectors (Dunning \& Lundan, 2008). Despite the topicality of this issue, no agreement has yet been reached on the impact of FDI on the market structures of the host country. Existing empirical studies on the effects of FDI on host country market structure are not extensive but show that growing FDI inflows affect host country market structure by improving or worsening competitive market conditions (Dunning \& Landan, 2008; Forte \& Sarmento, 2012; Driffield, 2001; Rutkowski, 2006; Ames \& Roberts, 2005; Lall, 1979). Most empirical studies on the relationship between FDI and the host country's market concentration relate to the manufacturing industry (Forte \& Sarmento, 2012; Singh, 2011; Rutkowski, 2006; Adam \& Khalifah, 2012; Yun \& Lee, 2001).

Forte and Sarmento (2012) examined the effects of FDI on market structures in the Portuguese manufacturing industry using data from 2006 to 2009 and applying a panel analysis. The concentration ratio of the four largest companies (CR4) was used as a dependent variable and a measure of market concentration, while the share of foreign companies in the total sales of the manufacturing 
industry was used as an explanatory variable and a proxy of FDI. Besides, market size, market growth rate, economies of scale and other variables were included in the analysis. The results of the research showed that there are negative effects of FDI on the level of market concentration in the manufacturing industry of Portugal.

Orazalin and Dulambaeva (2013) examined the effects of FDI on the level of market concentration in the manufacturing industries of 26 countries in Central and Eastern Europe and the Commonwealth of Independent States (CIS) using the instrumental variables method. FDI stock for 2000 was used as an independent variable, while dummy variable was used as a proxy of market concentration ( 1 if the company has 1-4 competitors (high market concentration), 0 if the company has more than four competitors (low market concentration). The results of the research showed that there is a negative impact of FDI on the market concentration of the host country, which is in line with the results of Forte and Sarmento (2012).

Driffield (2001) also studied the relationship between FDI and market concentration levels in the UK manufacturing industry between 1983 and 1992, using the method of simultaneous equations. According to the results of the research, FDI reduced the level of market concentration and improved the competitive conditions in the manufacturing industry of the United Kingdom.

Rutkowski (2006) also identified the negative impact of FDI on the level of market concentration in the manufacturing industry of 13 Central and Eastern European countries using data for 2001.

Lundin, Sjoholm, He and Qian (2007) examined the effects of FDI on the level of market concentration in the Chinese manufacturing industry from 1998 to 2004. The authors found that FDI inflows increased competition in the Chinese manufacturing industry (negative effects on the level of market concentration).

Singh (2011) also examined the effects of FDI on the level of market concentration in the manufacturing industry, but his research related to the manufacturing industry of India. The research was conducted from February 2001 to July 2006 using a panel analysis of data. Unlike Forte and Sarmento (2012) which used the concentration ratio of the four largest companies (CR4), Singh (2011) used the concentration ratio of the three largest companies in the manufacturing industry (CR3) as a dependent variable. The share of foreign companies in the total sales of the manufacturing industry was used as a proxy of FDI, while the market growth rate was also included as an explanatory variable. The results of the research showed that there is a statistically significant positive impact of FDI on the level of market concentration in the 
Indian manufacturing industry. Besides, the results showed that the change in the share of foreign companies in the total sales of the manufacturing industry by one unit, increases the level of market concentration by $24.90 \%$, while all other conditions remain unchanged.

Yun and Lee (2001) also studied the impact of FDI on the market structures of the host country by analysing the Korean manufacturing industry from 1991 to 1997. The authors concluded that there is a statistically significant positive impact of FDI on the level of market concentration measured through the concentration ratios of the three largest companies in the manufacturing industry (CR3). The obtained results are in line with the results of Adam and Khalifah (2012), Blomstrom (1986), Bourlakis (1987), Willmore (1989) who found the positive effects of FDI on the level of market concentration in the manufacturing industries of Malaysia, Mexico, Greece and Brazil.

Besides empirical studies examining the relationship between FDI and the level of market concentration in the manufacturing industry, certain studies have examined this relationship in the banking sector, especially in Indonesia. Cho (1990) examined the impact of FDI on the level of market concentration in the Indonesian banking market. The research was conducted from 1974 to 1983. The concentration ratio of the four largest banks in Indonesia (CR4) was used as a dependent variable, while the volume of FDI was used as an independent variable. The results of the research showed that the increase in the volume of FDI decreases the level of market concentration in the banking sector of Indonesia.

Mulyaningsih (2014) examined the relationship between FDI and conditions of competition also in the banking sector of Indonesia from 1980 to 2010 using the Vector Error Correction Model (VECM). The results showed that there is a long-term relationship between FDI and competition in the Indonesian banking sector. Besides, it was found that if there is a larger number of banks in the market and a favourable macroeconomic environment, then there is an increase in competition in the banking sector.

Panjaitan, Primiana, Ariawati and Masyita (2016) also examined the effects of FDI on the level of market concentration in the Indonesian banking sector. Data from 2005 to 2014 were used. The share of foreign banks in the total assets of the banking sector was used as a proxy of FDI and an independent variable, while the concentration ratio of the three largest banks (CR3) was used as a proxy of market concentration levels and dependent variable. The authors found that an increase in FDI (share of foreign banks in total assets of the banking sector) by one unit leads to a decrease in the level of market concentration 
(CR3) by 0.35 units. The obtained results are following the results obtained by Cho (1990) in his research.

Sathye (2002), as well as Ames and Roberts (2005) found that there is no relationship between FDI and the level of market concentration. Sathye (2002) examined this relationship in the banking sector of India from 1997 to 1998 using the Herfindahl-Hirschman Index (HHI) as a dependent variable, and as an independent variable and a proxy of the FDI, dummy variable that takes the value 0 if the bank is in the majority domestic ownership and value one if the bank is in the majority foreign ownership. Ames \& Roberts (2005) found that there is no impact of FDI on the level of market concentration in the Polish manufacturing industry using the instrumental variable method.

According to the mentioned empirical researches which examine the effects of FDI on the level of market concentration, it can be determined that the obtained results are inconsistent and differ depending on the observed country, market, period, research methodology and data used. Besides, according to a review of the relevant literature available to the author of this study, empirical study that examines the impact of FDI on the level of market concentration in the financial leasing sector could not be found, and there is no research related to the Republic of Serbia.

\section{METHODOLOGY}

The model used in the paper was formed according to the model of Sathye (2002), Panjaitan et al. (2016) and Forte and Sarmento (2012) with certain adjustments adequate to the nature and structure of the data of the financial leasing sector of the Republic of Serbia. Accordingly, the initial model is represented by the following equation:

$$
H H I_{t}=b_{1} F P_{t}+b_{2} M S \text { growth }{ }_{t}+c+\varepsilon_{t}
$$

where $H H_{t}$ - Herfindahl-Hirschman Index, a proxy of the level of market concentration in the financial leasing sector of the Republic of Serbia in the period $t$; $F P_{t}$ - the share of foreign companies in the total assets of the financial leasing sector of the Republic of Serbia in period $t, a$ proxy of FDI; $M S$ growt $_{t}$ - growth rate of the financial leasing market of the Republic of Serbia in period $t$ expressed as the growth rate of assets of the observed sector; $\varepsilon_{t}$ - error term in period $t$; $c$ - constant; $t=Q 1$ 2006, ..., Q1 2019.

Accordingly, general and specific research hypotheses have been set. 


\section{General research hypothesis:}

$\mathrm{H}_{0}$ : FDI inflows affect the level of market concentration in the financial leasing sector of the Republic of Serbia.

$\mathrm{H}_{1}$ : FDI inflows do not affect the level of market concentration in the financial leasing sector of the Republic of Serbia.

\section{Specific research hypotheses:}

$\mathrm{H}_{0 \mathrm{a}}$ : In the long run, FDI inflows have a positive effect on the level of market concentration in the financial leasing sector of the Republic of Serbia.

$\mathrm{H}_{1 \mathrm{a}}$ : In the long run, FDI inflows negatively affect or do not affect the level of market concentration in the financial leasing sector of the Republic of Serbia.

$\mathrm{H}_{0 \mathrm{~b}}$ : In the short run, FDI inflows have a positive effect on the level of market concentration in the financial leasing sector of the Republic of Serbia.

$\mathrm{H}_{1 \mathrm{~b}}$ : In the short run, FDI inflows negatively affect or do not affect the level of market concentration in the financial leasing sector of the Republic of Serbia.

The research used secondary data from the first quarter of 2006 to the first quarter of 2019, retrieved from the Report on the Financial Leasing Sector in Serbia of the Bank Supervision Department of the National Bank of Serbia. Descriptive statistics, unit root tests and the Autoregressive Distributed Lag (ARDL) approach were used for data analysis. According to Ghatak and Siddiki (2001), the ARDL approach gives statistically significant results even on relatively small samples. The ARDL approach is used when the variables are of a different order of integration, $\mathrm{I}(0)$, I(1) or a combination thereof, but no variable is $\mathrm{I}(2)$. The bound test is used to determine the long-term relationship between variables and is based on Wald's transformation of $\mathrm{F}$ statistics. If the value of F-statistics is higher than the upper $\mathrm{I}(1)$ and lower limit $\mathrm{I}(0)$ at the level of statistical significance of $10 \%, 5 \%$ and $1 \%$, it shows that there is a long-term relationship between variables (Nkoro and Uko, 2016).

\section{RESULTS AND DISCUSSION}

The Herfindahl-Hirschman Index (HHI) is the sum of the squares of individual market shares of companies in one industry, taking into account the existence of differences in the size of market share between competitors (Kostić, 2008). Begović, Bukvić, Mijatović, Paunović, Sepi and Hiber (2002) believe that markets with HHI index value less than 1000 have low concentration, the value from 1000 to 1800 medium concentration, from 1800 to 2600 high concentration, from 2600 to 10000 very high concentration, and monopolies have an HHI index value of 10000 . Table 1 shows the descriptive statistics of 
the variables. The average value of the HHI concentration index from the first quarter of 2006 to the first quarter of 2019 is 1243.13, showing that the financial leasing market in the Republic of Serbia is moderately concentrated on average. However, in the observed period, the HHI index on the financial leasing market of the Republic of Serbia ranges from the low concentrated (from the third quarter of 2012 to the first quarter of 2016, with the lowest value recorded in the first quarter of 2015) to highly concentrated (in the first and second quarters of 2006). The growth of the level of market concentration in the first quarter of 2006 is primarily the result of the growth of the market share of Raiffeisen Leasing d.o.o. Belgrade (National Bank of Serbia, 2006). In the first two quarters of 2006, Hypo-Alpe-Adria Leasing had the largest share in the financial leasing market (over $30.00 \%$ share in total assets). This period was also marked by the entry into the market of two new leasing companies: Intesa Leasing (in the first quarter) and EFG Leasing (in the second quarter), which had the lowest market share in the observed periods. In addition to these companies, Sogelease Serbia had the lowest market share $(0.10 \%)$ in this period. Three companies (Hypo Alpe-Adria Leasing, Raiffeisen Leasing and SLeasing in majority foreign ownership) retained market leadership in 2006. Still, their cumulative share decreased by more than ten percentage points compared to 2005, primarily due to the reduction of S-Leasing's share in the total assets of the financial leasing market (National Bank of Serbia, 2006).

Table 1

Descriptive statistics of variables

\begin{tabular}{lccccc}
\hline Variable & Mean & $\begin{array}{c}\text { Standard } \\
\text { deviation }\end{array}$ & Minimum & Maximum & $\begin{array}{c}\text { Number of } \\
\text { observations }\end{array}$ \\
\hline HHI & 1243.13 & 284.21 & 821.30 & 1877.20 & 53 \\
FP & 63.81 & 27.10 & 9.70 & 92.80 & 53 \\
MS growth & 1.18 & 5.75 & -12.91 & 15.48 & 53 \\
\hline
\end{tabular}

Note. Author's calculations.

After the second quarter of 2006, the financial leasing market became a medium-concentrated market. It remained so until the second quarter of 2012, but again became moderately concentrated from the second quarter of 2016 to the first quarter of 2019. In the first quarter of 2019, a total of 16 companies operated on the financial leasing market of the Republic of Serbia, with seven companies being foreign-owned and nine companies domestically owned. The four largest companies on the market had a $60.60 \%$ share in the total assets of the financial leasing sector in the first quarter of 2018 (PwC Serbia, 2019). In the observed period, at least 16 and at most 17 financial leasing companies 
operated on the financial leasing market of the Republic of Serbia, while the number of foreign-owned companies ranged from 7 to 11 .

According to the methodology of the National Bank of Serbia, foreign companies in the financial leasing sector of the Republic of Serbia are considered to be lessors if they are entirely (100\%) or majority-owned by foreign legal entities. Figure 1 shows the share of foreign companies in the total assets of the financial leasing sector of the Republic of Serbia in the observed period, where there is a declining trend in the share of foreign companies. The share of foreign companies in the total assets of the financial leasing sector of the Republic of Serbia (FP) in the observed period ranges from $9.70 \%$ in the fourth quarter of 2018 to $92.80 \%$ in the first quarter of 2006, with the average share of foreign companies in total assets of the financial leasing sector leasing of $63.81 \%$.

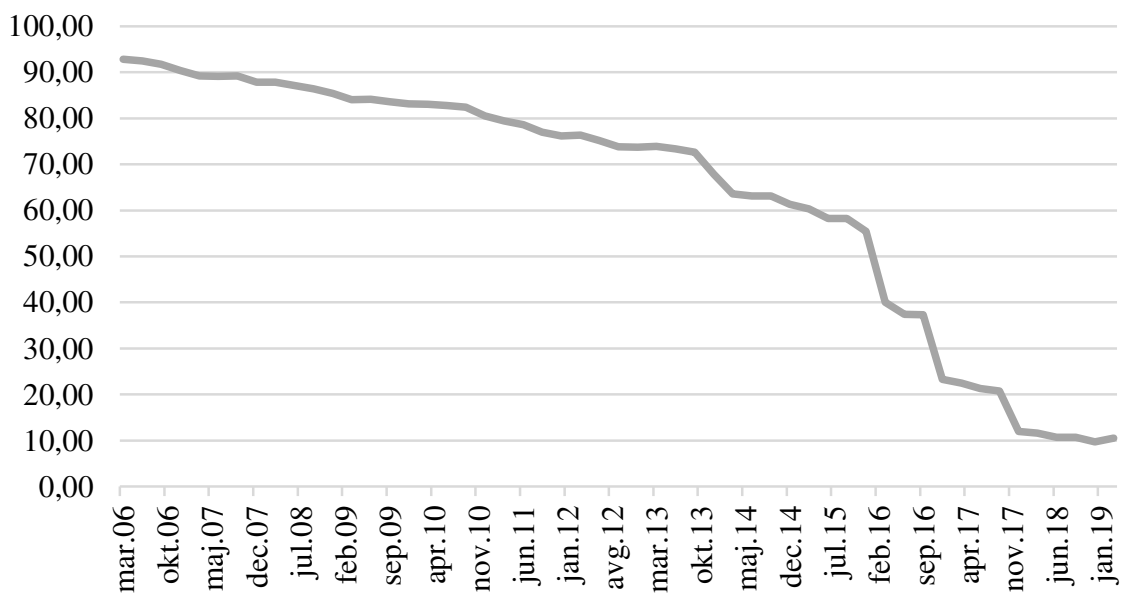

Figure 1. The share of foreign companies in the total assets of the financial leasing sector of the Republic of Serbia (FP), Q1 2006 - Q1 2019.

Note. Author's calculations.

The average growth rate of the financial leasing market of the Republic of Serbia in the observed period is $1.18 \%$. The minimum growth rate is -12.91 and refers to the first quarter of 2015, while the maximum growth rate is 15.48 and refers to the fourth quarter of 2008.

Augmented Dickey-Fuller (ADF) and Phillips-Perron (PP) unit root tests were used to examine whether the variables were of the same order of integration (Dickey \& Fuller, 1981; Phillips \& Perron, 1988). The results of unit root tests (Table 2) showed that the variables HHI and FP are stationary at the first differences $(\mathrm{I}(1))$, while the variable MS growth is stationary at the level $(\mathrm{I}(0))$. 
10 | MARKET CONCENTRATION AND FOREIGN DIRECT INVESTMENT IN THE FINANCIAL LEASING SECTOR OF THE REPUBLIC OF SERBIA

Since the variables are of a different order of integration, for the analysis of the relationship between the variables HHI, FP and MS growth it is possible to apply the ARDL approach which allows the variables in the model to have different lags, the most optimal for each variable and includes bounds test (Pesaran et al., 2001).

Table 2

Unit root test results $(A D F$ and $P P)$

\begin{tabular}{lcccc}
\hline & \multicolumn{2}{c}{ ADF test } & \multicolumn{2}{c}{ PP test } \\
\cline { 2 - 5 } Variable & Intercept & $\begin{array}{c}\text { Trend and } \\
\text { intercept }\end{array}$ & Intercept & $\begin{array}{c}\text { Trend and } \\
\text { intercept }\end{array}$ \\
\hline$H H I$ & -2.53 & -1.00 & -2.35 & -1.08 \\
$D(H H I)$ & $-5.94^{*}$ & $-6.58^{*}$ & $-5.98^{*}$ & $-6.58^{*}$ \\
$F P$ & -1.38 & -1.15 & 1.42 & -1.14 \\
$D(F P)$ & $-6.74^{*}$ & $-7.20^{*}$ & $-6.84^{*}$ & $-7.20^{*}$ \\
$M S$ growth & $-4.11^{*}$ & $-4.08^{*}$ & $-4.05^{*}$ & $-4.03^{*}$ \\
\hline
\end{tabular}

Note. Author's calculations.

Akaike Information Criteria (top 20 models)

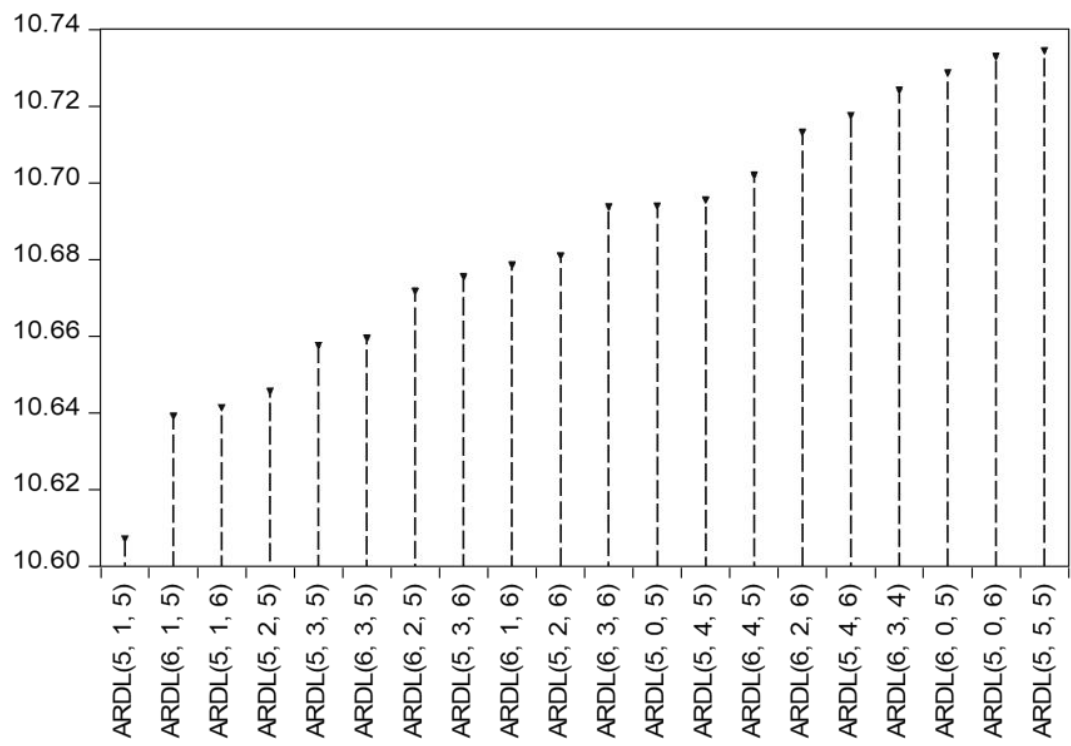

Figure 2. Selection of the optimal ARDL model according to the Akaike information criterion

Note. Author's calculations. 
The Akaike Information Criteria (AIC) was used to determine the optimal lag length and the optimal model because it provides more robust and reliable information compared to other information criteria, i.e. it does not identify the simplest model as optimal (Lutkepohl, 2006). The Akaike information criteria identified ARDL $(5,1,5)$ as the optimal model (Figure 2).The trend component is also included in the model because the existence of a trend in the observed variables has been determined.

Table 3

Bounds test

\begin{tabular}{lcccc}
\hline F-Bounds Test & \multicolumn{3}{c}{ Null hypothesis: No levels relationship } \\
\hline Test Statistic & Value & Signif. & I(0) & I(1) \\
\hline F-statistic & 6.99 & $10 \%$ & 4.19 & 5.06 \\
k & 2 & $5 \%$ & 4.87 & 5.85 \\
& & $1 \%$ & 6.34 & 6.52 \\
\hline
\end{tabular}

Note. Author's calculations.

The bounds test was used to examine the long-term relationship between the variables HHI, FP and MS growth, i.e., between the levels of market concentration, FDI and the growth rate of the financial leasing market in the Republic of Serbia. The bounds test is based on Wald's transformation of $F$ statistics and tests the null hypothesis that there is no long-run relationship between the variables HHI, FP, and MS growth. Since the value of F-statistics is greater than the upper $\mathrm{I}(1)$ and lower limit $\mathrm{I}(0)$ at $10 \%, 5 \%$ and $1 \%$ significance level, then the null hypothesis is rejected. Therefore, there is a long-term relationship between variables HHI, FP and MS growth. According to the results shown in Table 3, we can conclude that there is a long-term relationship between the variables HHI, FP and MS growth, i.e., cointegration between the level of market concentration, FDI and the growth rate of the financial leasing market in the Republic of Serbia.

Table 4

Long-term coefficients of the relationship between HHI, FP and MS growth

\begin{tabular}{lcccc}
\hline Variable & Coefficient & Std. Error & $\mathbf{t}$ & $\mathbf{p}$ \\
\hline FP & -13.83 & 5.03 & -2.75 & 0.01 \\
MS growth & 6.65 & 12.74 & 0.52 & 0.60 \\
\hline
\end{tabular}

Note. Author's calculations. 
Since the existence of a long-term relationship between variables has been determined (Table 3), it is necessary to calculate and evaluate long-term coefficients (Table 4).

These estimates also include the estimations of the error correction term (ECT), which shows the speed of adjustment towards equilibrium (Table 5). According to the results in Table 5, the error correction term is negative $(-0.32)$ and statistically significant $(\mathrm{p}<0.01)$, which shows that the system returns to equilibrium $32.00 \%$ quarterly, i.e., the system will be in equilibrium for less than a year (3 quarters and 11 days).

Long-term coefficients and their estimates show that the share of foreign companies in the total assets of the financial leasing sector of the Republic of Serbia (FP - a proxy of FDI) has a statistically significant and negative effect on the HHI index (a proxy of level of market concentration). Consequently, FDI has a statistically significant and negative impact on the level of market concentration in the financial leasing sector of the Republic of Serbia in the long run. The results also showed that in the long run, there is no statistically significant impact of market growth rate (MS growth) on the level of market concentration. Equation (2) shows the long-term relationship between the variables and the error correction term:

$$
E C T=H H I-(-13.83 * F P+6.65 * M S \text { growth })
$$

The results of the ARDL approach for the short-term relationship between variables FP and HHI differ from the results obtained for the long-term relationship of these variables (Table 5). Namely, suppose we observe the shortterm effect of FDI on the level of market concentration in the financial leasing sector of the Republic of Serbia. In that case, it can be concluded that there is no statistically significant impact of variable FP on the dependent variable HHI (p $>0.05$ ) at $5 \%$ significance level, while in the long-term a statistically significant relationship between the variables was found. Short-term coefficients of the relationship between $\mathrm{HHI}$ and MS growth showed that there is a statistically significant negative impact of the growth rate of the financial leasing market of the Republic of Serbia with a lag of 4 quarters on the level of market concentration in this sector, while the results obtained for long-term coefficients showed that there is no relationship between these variables (Table 5). 
Table 5

Short-term coefficients of the relationship between HHI, FP and MS growth

\begin{tabular}{lcccc}
\hline Variable & Coefficient & Std. Error & $\mathbf{t}$ & $\mathbf{p}$ \\
\hline D(HHI(-1)) & 0.19 & 0.12 & 1.64 & 0.11 \\
D(HHI(-2)) & 0.11 & 0.11 & 0.97 & 0.34 \\
D(HHI(-3)) & 0.23 & 0.11 & 2.03 & 0.05 \\
D(HHI(-4)) & 0.67 & 0.14 & 4.84 & 0.00 \\
D(FP) & 1.57 & 2.20 & 0.71 & 0.48 \\
D(MS growth) & 5.18 & 1.41 & 3.69 & 0.00 \\
D(MS growth(-1)) & 0.16 & 1.72 & 0.09 & 0.93 \\
D(MS growth(-2)) & 2.12 & 1.65 & 1.28 & 0.21 \\
D(MS growth(-3)) & 0.71 & 1.67 & 0.42 & 0.67 \\
D(MS growth(-4)) & -5.64 & 1.43 & -3.83 & 0.00 \\
ECT(-1) & -0.32 & 0.07 & -4.72 & 0.00 \\
C & 1015.28 & 212.35 & 4.78 & 0.00 \\
@trend & -12.00 & 2.51 & -4.78 & 0.00 \\
\hline R-squared & 0.64 & Mean dependent var & -7.68 \\
Adj. R-squared & 0.52 & S. D. dependent var & 60.12 \\
S. E. of regression & 41.59 & Akaike info criterion & 10.52 \\
Sum squared resid & 60566.83 & Schwarz criterion & 11.03 \\
Log-likelihood & -239.48 & Hannan-Quinn crietr. & 10.71 \\
F-statistic & 5.26 & Durbin-Watson stat & 2.02 \\
Prob (F-statistic) & 0.00 & \multicolumn{4}{c}{} \\
\hline
\end{tabular}

Note. Author's calculations.

The basic assumptions of the model, the normal distribution of the residuals, the absence of serial correlation and heteroskedasticity are fulfilled. If the number of observations in the sample is greater than 30 than each empirical distribution, according to the central limit theorem, tends to be normal, so each empirical distribution, for $n>30$ can be approximated by normal (Jovetić, 2015). Since the sample has 53 observations, it is considered that the assumption of a normal distribution of residues is fulfilled. A serial correlation test was done using the Breusch-Godfrey Serial Correlation LM test. The test is performed by regressing the residuals to the model variables and the residuals with a lag (Jovetić, 2015). The null hypothesis that there is no serial correlation is tested. Since the test results showed that the null hypothesis could not be rejected, it is concluded that the assumption of no serial correlation is fulfilled (Table 6). Durbin-Watson statistics ( $\mathrm{DW}=2.02$ ) show that there is no autocorrelation problem in the model. Field (2009) finds that the value of Durbin-Watson statistics below one and above three are worrying when testing autocorrelation. 
14 | MARKET CONCENTRATION AND FOREIGN DIRECT INVESTMENT IN THE FINANCIAL LEASING SECTOR OF THE REPUBLIC OF SERBIA

Table 6

Breusch-Godfrey LM serial correlation test results

\begin{tabular}{cccc}
\hline F-statistic & Prob. F(5, 28) & Obs*R-squared $^{*}$ & $\begin{array}{c}\text { Prob. Chi- } \\
\text { square (5) }\end{array}$ \\
\hline 0.27 & 0.92 & 2.24 & 0.82 \\
\hline
\end{tabular}

Note. Author's calculations.

The assumption of the constant variance of the residuals means that for each value of the independent variable the value of the residuals shows the same dispersion around its mean value, which means that the residuals are homoskedastic (Jovetić, 2015).

Table 7

Breusch-Pagan-Godfrey heteroskedasticity test results

\begin{tabular}{cccccc}
\hline F-statistic & $\begin{array}{c}\text { Prob. F } \\
(\mathbf{1 4}, \mathbf{3 3})\end{array}$ & $\begin{array}{c}\text { Obs*R- } \\
\text { squared }\end{array}$ & $\begin{array}{c}\text { Prob. Chi- } \\
\text { square (14) }\end{array}$ & $\begin{array}{c}\text { Scaled } \\
\text { explained } \\
\text { SS }\end{array}$ & $\begin{array}{c}\text { Prob. Chi- } \\
\text { square (14) }\end{array}$ \\
\hline 0.66 & 0.79 & 10.46 & 0.73 & 8.36 & 0.87 \\
\hline
\end{tabular}

Note. Author's calculations.

Testing of this assumption was performed using the Breusch-Pagan-Godfrey heteroskedasticity test. The null hypothesis that residuals are homoskedastic is tested. The test results showed that the null hypothesis could not be rejected, which shows that the assumption was fulfilled (Table 7).

An important assumption of the evaluated ARDL model is its stability, which is tested using the CUSUM and CUSUM of Squares test (Page, 1954). The test results on the existence of recursive residuals for means and variances are shown in Figures 3. The dashed lines on the graphs show bounds of 5\% statistical significance. If the recursive residues are within the limits of $5 \%$ of statistical significance, then it is concluded that the estimates of a short-term and long-term relationship, i.e. the estimated ARDL model, are valid and stable. Finally, the results of the F-test are statistically significant at the $1 \%$ significance level, which shows that the model is stable and statistically significant. According to the above results, testing the assumptions of the ARDL model concludes that the model is reliable and stable. 

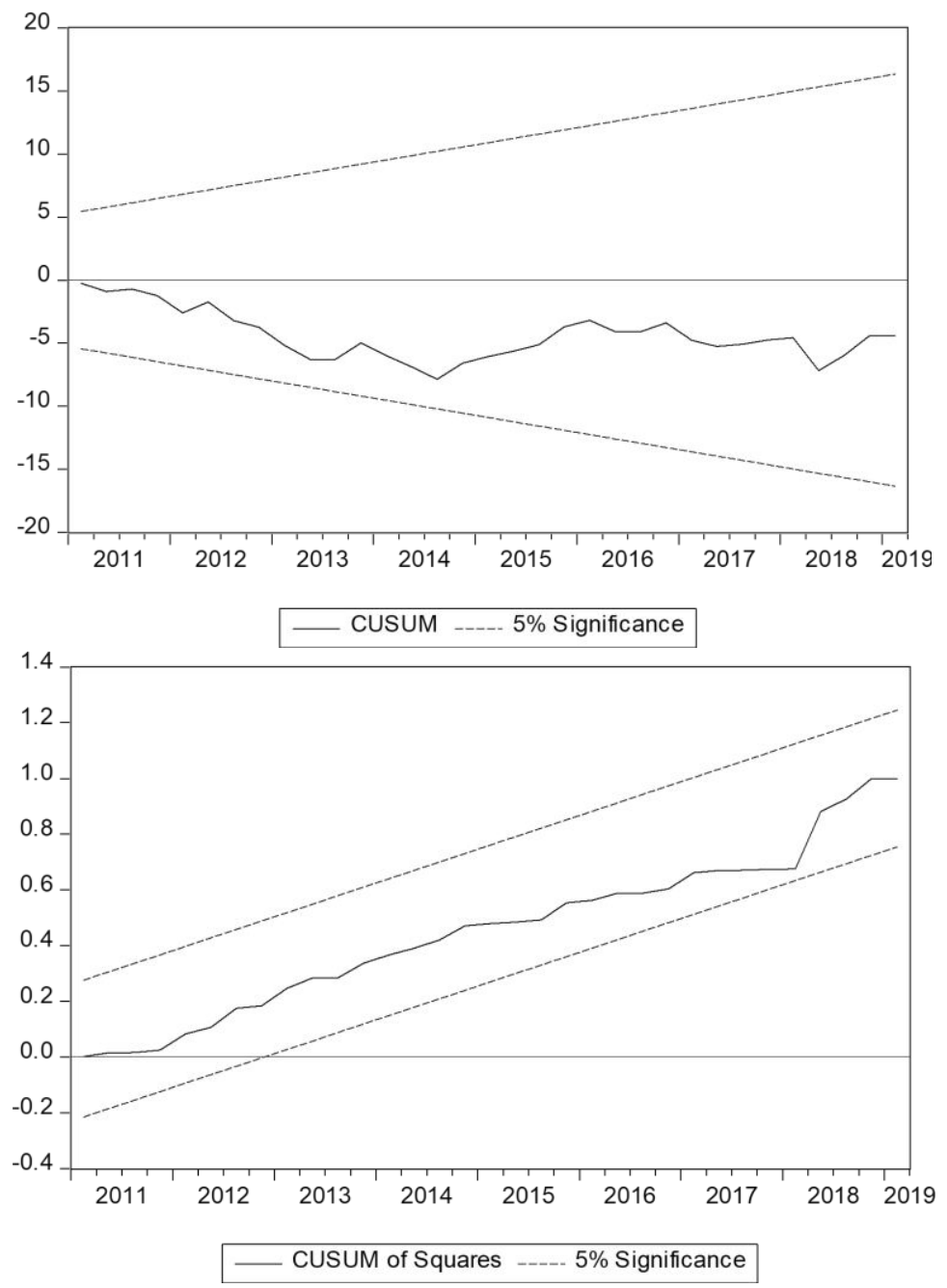

Figure 3. CUSUM and CUSUM of squares test results Note. Author's calculations.

\section{CONCLUSION}

This empirical study investigates the relationship between FDI inflows and the level of market concentration in the financial leasing sector of the Republic of Serbia using the ARDL model. The results of the research showed a statistically significant negative impact of FDI inflows on the level of market concentration in the financial leasing sector of the Republic of Serbia in the long run. 
The paper confirms the general null hypothesis $\left(\mathrm{H}_{0}\right)$ and concludes that FDI inflows affect the level of market concentration in the financial leasing sector of the Republic of Serbia. Also, it is stated that within the first group of specific research hypotheses, the null hypothesis was rejected, and the alternative hypothesis $\left(\mathrm{H}_{1 \mathrm{a}}\right)$ was accepted, so it is concluded that in the long run, FDI inflows negatively affect the level of market concentration in the financial leasing sector.

The obtained results are following the results of Forte and Sarmento (2012), Orazalin and Dulambaeva, Driffield (2001), Rutkowksi (2007), Lundin et al. (2007) who found a negative relationship between FDI and the level of market concentration in the manufacturing industry but are also consistent with the results of Cho (1990), Panjaiatna et al. (2016) who found a negative relationship between these variables in the banking sector. Besides, it was determined that the system returns to equilibrium at a speed of $32.00 \%$ quarterly, i.e., in 3 quarters and 11 days.

The results of the research also show that in the short run, there is no relationship between FDI and the level of market concentration. In accordance with the above, it is stated that within the second group of specific research hypotheses, the null hypothesis was rejected. The alternative hypothesis $\left(\mathrm{H}_{1 \mathrm{~b}}\right)$ was accepted. Therefore, it is concluded that in the short run, FDI inflows do not affect the level of market concentration in the financial leasing sector of the Republic of Serbia.

According to the author's knowledge, this is the first empirical study that examines the relationship between FDI and the level of market concentration in the financial leasing sector of the Republic of Serbia, which makes a significant contribution to the existing literature. This study contributes to a better understanding of the relationship between FDI inflows and market concentration in the financial leasing sector and indicates that increasing the share of FDI inflows in this sector reduces the level of market concentration, in the long run, leading to increased market competition.

The results of the research of this empirical study provide appropriate information and guidelines for future directions of development of the financial leasing market of the Republic of Serbia, which shows its practical contribution. The users of this empirical data can be decision-makers, policymakers and other interested participants in the field of financial leasing.

Future research in this problem area should be extended to multi-country financial leasing markets to apply a panel analysis of data and compare the results between countries. Besides, it is necessary to include several variables in 
the analysis that may affect the market structures of the host country (entry barriers in the industry, market size, etc.).

\section{REFERENCES}

Adam, R., \& Khalifah, N. (2012). Foreign Presence and Market Concentration in Malaysian Manufacturing Industries. Jurnal Ekonomi Malaysia, 46(1), 119-132.

Ames, K., \& Roberts, B. (2005), The impact of foreign and state ownership on post transition industrial concentration: the case of Polish manufacturing. Economic Change, 38(3-4), 211-225.

Begović, B., Bukvić, R., Mijatović, B., Paunović, M., Sepi, R., \& Hiber, D. (2002). Antimonopolska politika u SR Jugoslaviji. Beograd: Centar za liberalno-demokratske studije.

Blomstrom, M. (1986). Multinationals and Market Structure in Mexico. World Development, 14(4), 523-530.

Bourlakis, C., A. (1987). Multinational Corporations and Domestic Market Structure: The Case of Greek Manufacturing Industries. Review of World Economics, 123(4), 719-733.

Cho, K., R. (1990). Foreign Banking Presence and Banking Market Concentration: The Case of Indonesia. Journal of Development Studies, 27(1), 98-110.

Čavić, D. (2009). Računovodstveno obuhvatanje nabavke osnovnih sredstava putem finansijskog lizinga. Škola biznisa, 111-118.

Dickey, D., A., \& Fuller, W., A. (1981). Likelihood ratio statistics for autoregressive time series with a unit root. Econometrica, 49(4), 10571072.

Driffield, N. (2001). Inward Investment and Host Country Market Structure: The Case of the UK. Review of Industrial Organization, 18(4), 363378.

Drljača, S. (2015). Finansijski lizing u Srbiji i uzroci saturacije tržišta. Ekonomski vidici. 20(1), 65-81.

Dunning, J. H., \& Lundan, S. M. (2008). Multinational Enterprises and the Global Economy, $2^{\text {nd }}$ Edition. Massachusetts: Edward Elgar Publishing, Inc.

Field, A. (2009). Discovering Statistics Using SPSS, $3^{\text {rd }}$ edition. London: Sage. 
18 | MARKET CONCENTRATION AND FOREIGN DIRECT INVESTMENT IN THE FINANCIAL LEASING SECTOR OF THE REPUBLIC OF SERBIA

Forte, R., \& Sarmento, P. (2012), Foreign Presence and Market Concentration: The Case of Portuguese Manufacturing Industries. FEP Working Papers $N^{\circ} 444$, Faculdade de Economia do Porto.

Grand View Research. (2019). Finance Lease Market Analysis, By Product, By Type, By Application, By Region, And Segment Forecasts, 2019 To 2025. Retrieved from www.grandviewresearch.com/industryanalysis/finance-lease-market

Ghatak, S., \& Siddiki, J. U. (2001). The use of the ARDL approach in estimating virtual exchange rates in India. Journal of Applied Statistics, 28(5), 573-583.

Jovetić, S. (2015). Merenje performansi preduzeća. Kragujevac: Ekonomski fakultet Univerziteta u Kragujevcu

Kostić, M. (2008). Merenje koncentracije ponude grane. Ekonomski horizonti, 10(1), 95 .

Lall, S. (1979). Multinational and Market Structure in an open Developing Economy: The Case of Malaysia. Review of World Economies, 115(2), 325-350.

Lundin, N., Sjoholm, F., He, P., \& Qian, J. (2007) FDI, Market Structure and R and D Investments in China. Working Paper No. 708, The International Centre for the Study of East Asian Development, Kitakyushu.

Mulyaningsih, T. (2014). Banking competition and its relationship with banking stability: Evidence from Indonesia 1980-2010. (PhD Thesis). Indonesia: Faculty of Business, Government and Law.

Narodna banka Srbije. Izveštaj o sektoru finansijskog lizinga u Srbiji. (2006)

Nkoro, E., \& Uko, A. K. (2016). Autoregressive Distributed Lag (ARDL) cointegration technique: application and interpretation. Journal of Statistical and Econometric Methods, 5(4), 63-91.

Orazalin, R., \& Dulambaeva, R. (2013). FDI Impact on Host Country's Market Concentration and Profitability. Actual Problems of Economics, 139, 428-438.

Pack, H., \& Saggi, K. (2001). Vertical technology transfer via international outsourcing. Journal of Development Economics, 65(2), 389-415.

Page, E. S. (1954). Continuous inspection schemes. Biometrika, 100-115.

Panjaitan, R., Primiana, I., Ariawati, R. R., \& Masyita, D. (2016). The effect of foreign bank penetration on the banking concentration and its impact on 
financial stability in Indonesian banking industry. International Journal of Economics, Commerce and Management, 4(8), 197-210.

Pesaran, M. H., Shin, Y., \& Smith, R. J. (2001). Bounds testing approaches to the analysis of level relationships. Journal of Applied Econometrics, 16(3), 289326.

Phillips, P. C. B., \& Perron, P. (1988). Testing for a Unit Root in Time Series Regression. Biometrika. 75(2), 335-346.

PwC Srbija. Guide to Doing Business and Investing in Serbia. (2019).

Rutkowski, A. (2006). Inward FDI, concentration, and profitability in the CEECs: Were the domestic firms crowded out or strengthened? Transnational Corporations, 15(3), 105-140.

Sathye, M. (2002). The Impact of Foreign Banks on Market Concentration: The case of India. Applied Econometrics and International Development, 2(1), 7-20.

Singh, J. (2009). Foreign Direct Investment and Market Structure: Evidence from India's Manufacturing sector. Trivandrum: Centre for Development Studies.

Willmore, L. (1989). Determinants of Industrial Structure: A Brazilian Case Study. World Development, 17(10), 1601-1617.

Yun, M., \& Lee, S. (2001). Impact of FDI on Competition in Korean Manufacturing Industries: 1991-97. Korea: Institute for International Economic Policy.

Delivered: 20.04.2020. Accepted: 21.09.2020. 